\title{
Good Governance in Medium-Term Development Plan (Perencanaan Pembangunan Jangka Menengah Desa/RPJMDes) in Daerah Istimewa Yogyakarta
}

\author{
Ambar Teguh Sulistiyani ${ }^{1}$ \\ Departement of Public Policy and Management \\ Faculty of Social and Political Science UGM \\ Yogyakarta, Indonesia \\ atsulis@yahoo.co.id \\ Muammar Yuliana ${ }^{2}$ \\ The Center of Regional Development Planning UGM \\ Yogyakarta, Indonesia \\ moeammary@gmail.com
}

\author{
Kristi Yuliani ${ }^{3}$ \\ The Center of Regional Development Planning UGM \\ Yogyakarta, Indonesia \\ Yuliani.kristi@gmail.com \\ Sri Sulistiyani ${ }^{4}$ \\ The Center of Regional Development Planning UGM \\ Yogyakarta, Indonesia \\ srisulistyani@gmail.com
}

\begin{abstract}
The enactment of Law Number 6 of 2014 concerning Village has created consequences toward villages to improve the institutional capacity and the capability in development planning. Rencana Pembangunan Jangka Menengah Desa/ RPJMDes (Medium-Term Development Plan) is a form of development plan which adopt the design of comprehensive rational plan, which is the reflection of good governance practice. The research problem is, "how is the practice of good governance in the arrangement of RPJMDes by villages in DIY?"

This research aims to identify good governance practice in arranging RPJMDes in 40 sample villages in DIY. There were 10 village samples from each regency. The research methods used were quantitative and qualitative approach. Quantitative method was used to find out the stakeholder perspective, while qualitative method was used to obtain specific and unique information in explaining the arranging process of RPJMDes. This evaluation study illustrates good governance practice using some indicators, which are participative, siding with public, transparency, accountable, efficient, and effective.

The research result shows that the sample villages has applied good governance yet has not covered the entire indicators. There are six indicators which express good governance spirit in RPJMDes, but only some parts which have achieved good scores. In order to improve the quality of good governance practice in the arrangement of RPJMDes, the role of village counselors are needed to help Tim Sebelas and optimize the role of stakeholder by starting intensive communication through village media.
\end{abstract}

\section{Keywords—Good Governance; RPJMDes; Village Planning}

\section{INTRODUCTION}

RPJMDes (Rencana Pembangunan Jangka Menengah Desa/ Village Medium-Term Development Plan) is a form of development plan which adopted Rational Comprehensive Planning. At the moment, RPJMDes has a strong momentum to be implemented massively. The source funding of RPJMDes is from village specific fund, which is in accordance with the mandate of Law Number 6 of 2007 concerning village. Therefore, all villages should own RPJMDes document. In order to give guidance to villages in arranging RPJMDes, Ministry of Home Affairs issued Minister of Home Affairs Regulation Number 66 of 2007; and was followed by Minister of Home Affair Regulation Number 114 of 2014.

Since its enactment, Village Law has created consequences for villages to increase institutional capacity. Village as the vanguard in public service is demanded to be more efficient in giving the right proportion. However, the increasing quality in public service is still underestimated since it is only administrative service. This kind of perspective is not relevant anymore. Moreover, village has increasingly existing positions and roles. Along with the enactment of Village Law, innovation and creativity ability are required. As well as other government agencies, village should be able to perform its strategic roles in development.

RPJMDes is a guidance used by village government in performing its function to develop in a period of leadership of a village-head. In order to provide an umbrella to arrange RPJMDes, village government along with LPMD (Lembaga Pemberdayaan Masyarakat Desal Village Community Empowerment Agency), BPD (Badan Permusyawaratan Desa/Village Consensus Agency) and public figures, as representative from community, establish RPJMDes planning team called Tim Sebelas. DIY (Daerah Istimewa Yogyakartal Yogyakarta Special Region) is a province in Indonesia which has a specificity in government, known from its origin. DIY has an area consists of four regencies and a city. The villages located in the four regencies in DIY, which are 392 villages, are really concerned with governance boundary in the planning they do.

The dynamics in arranging RPJMDes by villages in DIY concerns with the provision of Minister of Home Affairs 
Regulation Number 66 of 2007 and Number 114 of 2014. Actually, these two regulations have contained the urgency to fulfill good governance provision in arranging RPJMDes. Village awareness of the importance to fulfill good governance provision indeed varies. This research collects data and information about How is the practice of good governance in the arrangement of RPJMDes by villages in DIY?

\section{RESEARCH METHODS}

This research was done using quantitative approach in order to generally observe the process of RPJMDes arrangement which express the good governance values. The comprehending of information for each indicator was done through comprehensive interview toward Tim Sebelas.

This research collected sample of 40 villages which were located near the central government in the four regencies. There were 10 village samples from each regency, with the details in Table 1.

TABLE 1. SAMPLE VILLAGES IN THE RESEARCH OF FOUR

\begin{tabular}{|l|l|}
\hline \multicolumn{1}{|c|}{ REGENCIES IN DIY } \\
\hline Sleman & \multicolumn{1}{|c|}{ Name of Sample Villages } \\
& $\begin{array}{l}\text { Caturharjo, Sumberadi, Tlogoadi, } \\
\text { Sendangadi, Triharjo, Tridadi, } \\
\text { Sinduharjo, Pandowoharjo, Sariharjo, } \\
\text { Trimulyo }\end{array}$ \\
\hline Bantul & $\begin{array}{l}\text { Trirenggo, Palbapang, Sumbermulyo, } \\
\text { Sumberagung, Guwosari, Sabdodadi, } \\
\text { Pendowoharjo, Bantul, Ringinharjo, } \\
\text { Timbulharjo }\end{array}$ \\
\hline Kulon Progo & $\begin{array}{l}\text { Tayuban, Triharjo, Giripeni, } \\
\text { Ngestiharjo, Kulwaru, Gotakan, } \\
\text { Bojong, Tawangsari, Karangsari, } \\
\text { Bendungan }\end{array}$ \\
\hline Gunungkidul & $\begin{array}{l}\text { Siraman, Karang Rejek, Wonosari, } \\
\text { Baleharjo, Karang Tengah, Ngipak, } \\
\text { Piyaman, Banaran, Kepek, Bejiharjo }\end{array}$ \\
\hline
\end{tabular}

Source:Research Result Report, Yogyakarta, 2017

The basic idea of sample choosing is that suburb villages have higher accessibilities to central regency government. In accordance with the high access, Tim Sebelas, in particular, and village government, in general, can perform consultation, access information, and obtain assistance faster. Consultation, information and assistance facilities in arranging RPJMDes become more intensive. The existence of intensive communication with the regency gives chance in improving good governance practice.urrent designations.

\section{LITERATURE REVIEW}

Before you begin to format your paper, first write and save the content as a separate text file. Keep your text and graphic files separate until after the text has been formatted and styled. Do not use hard tabs, and limit use of hard returns to only one return at the end of a paragraph. Do not add any kind of pagination anywhere in the paper. Do not number text headsthe template will do that for you.

Finally, complete content and organizational editing before formatting. Please take note of the following items when proofreading spelling and grammar:

\section{A. Cases in Some Countries}

The arrangement of development plan in village level is also developed in some other countries. In Tanzania and Malaysia, planning in village level is performed in order to keep the sustainability of development. Bello and Dola (2014:268) proposed "The Malaysian situation of local governance in the midst of quest for sustainable development." The effort taken by village in facilitating sustainable development needs community participation. Further, Bello and Dola (2014:273) also said "The clear dual functions of local governments in Germany are self-government and delegated tasks". In addition, the case in India according to Nagendra and Ostrom (2014:62) showed "The south Indian city Bangalore provides a challenging yet representative context within which to examine issues of governance of urban socialecological commons".

A development plan arranged needs to pay attention to environmental safety. Development should place environment as the main consideration. The goal in developing is to improve the current condition to a better one. A study carried by Oyeniyi and Ladeyem (2011:3) explained "The study first looks at security and later environmental security. A development pays attention to security problems in one side and environmental safety in the other side. A safe, good, healthy and comfortable environment can make people maintaining their live well. In some countries, the direction of village development cannot be separated from the effort to increase environmental quality.

\section{B. Roles, Functions and Village Government Duties}

Government has strategic role in improving village performance. The strategic role can work well if village had implementation guidance which is clearly, systematically and measurably composed. Based on this guidance, village government can implement some adhered roles. Hadi T. and Purnama L. (1996) proposed "The role of government apparatus is not only as facilitator and service provider but also as dynamist and entrepreneur". In accordance with this demand, village needs to have fix, innovative, progressive and comprehensive plan.

As conveyed by Suaib at.al. (2016:282), explicitly, the roles and functions of village is to manage village finance properly, which is inherent in the government functions and duties of the village namely governance, implementation of development, social development, and community empowerment. Village government covers the village government and BPD. Village performs government duties well as the executor of physical, social, and economy development in order to reach public welfare through empowerment.

\section{Village Development Planning}

Village development planning is an effort to compose all direction, goal, strategy, indicator, programs and activities in village. RPJMDes is periodic planning document arranged based on vision and mission of the elected village-head. The importance of village development planning according to Suhardi (2015:74) is to improve the entire resources capacity 
owned by village to support the improvement of the capacity. In addition, Tumenggung (2016:43) said, "Village financial management is a cycle that includes planning, implementation, administration, reporting and accountability, with the periode of one (1) fiscal year, starting from January 1 to December 31. Whereas, in Kazimoto's opinion (2013:112) said "financial management is in place, development project activities are implemented at the village level and are meant to enhance village socio-economic development". In addition, Bello and Dola (2014:270) proposed, "The role of governance in promoting development which is sustainable".

\section{Good Governance in RPJMDes}

The means of good governance in village government context is important to be comprehended. Good governance related to success determination in policy needs to be implemented by considering strategic moves so that the village government vision and mission can be reached successfully. Sebudubudu (2010:250) conveyed "Good governance is a critical policy requirement for a successful reduction strategy and human development progress of any country. In addition, Pippidi (2016:107) said "Good governance are of limited policy use".

Village development supposes to emphasize empowerment. Therefore, governance is focused on development based on humanity. The efforts to improve public welfare are done through programmed moves which are periodically managed. It is in accordance with Sebudubudu (2010:250) who said that governance and poverty receive close attention in development circles.

A development in general is performed for the sake of structural change. The transformation of knowledge, technology, and public behavior is really important to be maintained. A fix plan to develop should be arranged by government. Villages, particularly which have development accessibility through community empowerment approach, need to understand comprehensive development context and content. Miraftab (2008:1) proposed that local planning and governance structures, or about the consequences of these transformations. The entire transformations which has been performed really need response and positive relationship with community participation in terms of participation and sustainability. Whereas in Madhavi's opinion (2016:58) was "Governance is wider in nature which encompasses, the achievement, goals of economy, efficiency, ffectiveness and accountability".

The goal of development in a system of good governance is to improve community. The focus of development should be controlled wisely and strategically, considering the limited resources. The main priority of good governance in performing development is anticipating social economy gap. Therefore, improving welfare for the poor and marginal should be prioritized. Subramanian (2010:305) said "The challenge for all societies is to create a system of good governance that promotes supports and sustains human development - especially for the poorest and the most marginal".

Values which become the characteristics in arranging
RPJMDes document are democratization and good governance. Therefore, a development planning process should be based on consensus, as well as the emphasizing of the practice of good governance comprehensively.

Law Number 6 of 2014 concerning village gives mandate to all villages to arrange development plan consistently. Tumenggung (2016:42) proposed "Law Number 6 of 2014, provide a great opportunity for the village to take care of their own governance system".

Planning approach used is bottom-up planning. A consensus is done start from Rukun Tetangga (RT), Rukun Warga (RW), hamlet until village level. The spirit of this bottom-up planning is followed by participation indicator, empowerment, transparency, accountability, efficiency, and effectiveness. These six indicators are the expression of good governance spirit in RPJMDes. The Minister of Home Affairs Regulation Number 66 of 2007 accommodates 11 indicators; six of them are the indicator of good governance.

Eleven indicators of RPJMDes arrangement are:empowerment, participative, taking side with community, transparency, accountable, selective, efficiency and effective, sustainability, accurate, repeated process and based on data and information. The six indicators which are the expression of good governance are:participative, partiality to community which can be on the same level as responsive behavior, open, accountability, efficiency and effectiveness.

The role of government apparatus is not only as facilitator and service provider but also as dynamist and entrepreneur (Hadi T. and Purnama L., 1996). In accordance with this demand, hence village needs a fix, innovative, progressive and comprehensive plan.

The measurement of planning process in some countries are really concerned with community participation. In their research result, Bello and Dola (2014:272) said "Grass root is also initiated at the local level." Community participation is really important in planning, implementation until evaluation. In general, the form of participation according to Shockpea at. al. (2011:59) is "Actively participated in meetings to identify and prioritize their needs and identify locations for the project site." The start of participation from meetings until the selection of village/community priority list and the project location needs relatively long time.

A plan needs to be measured with some varied indicators. Some indicators are completing one another. As proposed by Suhardi (2015:73), development is marked by the existence of productivity, efficiency and community participation. In addition, Sutomo (2015:19) explained "APBDes policies should apply the principle of good governance that include participation, transparency and accountability so that the goal is done in village development can be achieved". Indicators proposed by Subramanian (2010:305) is "Good governance is among other things participatory, transparent and accountable". In addition, Martiah conveyed that "Good governance is a modern governance principles which are based on three main elements, namely accountability, transparency and public participation, particularly which needs regulation facility.

Some theories show the similarity of perspective in evaluating village development. Regarding the opinions from 
some experts and research results in some countries, the measurement of good governance practice in arranging village development document use some indicators:participation, partiality to community which can be on the same level as responsive behavior, transparency, accountability, efficiency and effectiveness.

\section{DATA ANALYSIS}

The process of RPJMDes arrangement is interactive dialogue between stakeholders in Tim Sebelas. The dialogue process varies in form, such as transaction of interests, actor role domination, focusing on individual strengths, role mobilization, active participation and sharing of Tim Sebelas in balanced manner. This evaluation study illustrates good governance practice using some indicators, which are participative, siding with public, tranparency, accountable, efficient, and effective.

The process of RPJMDes arrangement is interactive dialogue between stakeholders in Tim Sebelas. The dialogue process varies in form, such as transaction of interests, actor role domination, focusing on individual strengths, role mobilization, active participation and sharing of Tim Sebelas in balanced manner. This evaluation study illustrates good governance practice using some indicators, which are participative, siding with public, open tranparency, accountable, efficient, and effective.

\section{A. Participative Indicator}

Participation is contribution component from village government, social institution and community in composing RPJMDes. Diagram 1 shows the border of the highest score, average score and the lowest score gained by each village in each regency.

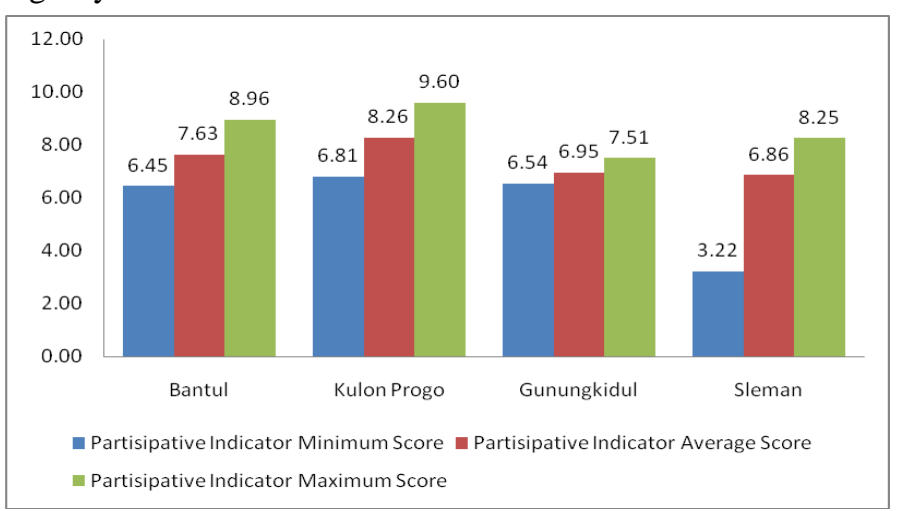

Fig 1. The Practice of Participation Indicator in the Process of RPJMDes Arrangement in the Four Regencies in DIY

Source:Processed from Primary Data, Yogyakarta, 2017

The highest score in participation to arrange RPJMDes is gained by village in Kulon Progo Regency with 9,60 points; village in Bantul Regency with 8,96 points and village in Sleman with 8,25 points. High average scores are gained by villages in Kulon Progo Regency and Bantul Regency. Average scores of participation in Gunungkidul Regency and Sleman Regency are under 7,00 while the lowest scores in Bantul Regency and Kulon Progo Regency are relatively good since they are over 6,45-6,81. Extreme point of the lowest score can be found at Sleman Regency with 3,22. Villages which have the widest participation score gap is Sleman Regency with scores gap up to 5 points. The lowest participation score gap is Gunungkidul Regency since the scores are relatively even. The high average scores of participation in Kulon Progo Regency and Bantul Regency are caused by four factors. First, the characteristic of people in Kulon Progo and Bantul is communal, which means that they care and empathize for one another; second, village counselor that works well; third, village social institutions and public figures that work well; fourth, consensus system for village development (Musyawarah Perencanaan Pembangunan Desa as name as MUSRENBANGDES) from RT, RW, and hamlets until villages that function well. Interview result with Tim Sebelas shows that "There are inputs about program coming from hamlet, PKK (Pembinaan Kesejahteraan Keluarga as name as Family Welfare Movement) and Karang Taruna (youth organization within village border)". However, after further observation, the participation has not been maximized and is more to participation in forum only yet does not use the right for speech. In an extreme point, the lowest participation score in Sleman Regency is caused by the community characteristic which is more urban and having low concern for one another.

\section{B. Partiality to Community}

The indicators for partiality to community in the process of RPJMDes arrangement in the four regencies illustrate low value gap which has been gained.

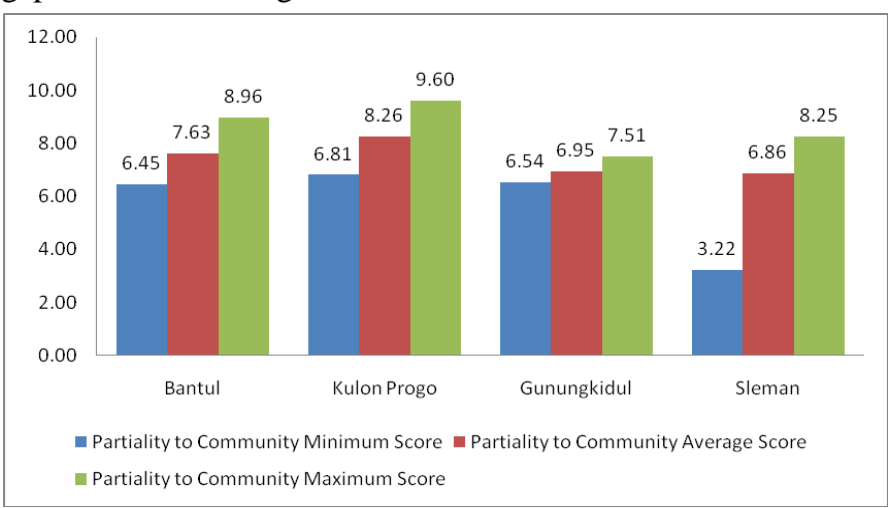

Fig 2. The Practice of Partiality to Community Indicator in the Process of RPJMDes Arrangement in the Four Regencies in DIY

$$
\text { Source:Processed from primary data, Yogyakarta, } 2017
$$

Good governance practice in the arrangement of RPJMDes, judging from the partiality to community, is in form of program plan which fulfill public urgency and need. The best partiality to community is in villages in Kulon Progo Regency and Bantul Regency. The score of partiality to community which is even with medium category occurs in villages in Gunungkidul Regency. Partiality to community score with wide gap occurs in villages in Sleman Regency. The high score and good average means that RPJMDes of villages in Kulon Progo Regency and Bantul Regency illustrating the capability of Tim Sebelas in accomodating public urgency and need. RPJMDes which is able to express community need shows that solidarity between village government and community exist. Villages in Gunungkidul Regency achieving medium score is caused by knowledge of RPJMDes planning which has not been widespread and village counselor that has not worked. Whereas, the lowest score of villages in Sleman Regency shows that village government and community is less solid as well as the absence of village counselor in planning. 


\section{Transparency}

The illustration of good governance practice which is measured by the indicator of transparency encounters basic problems.

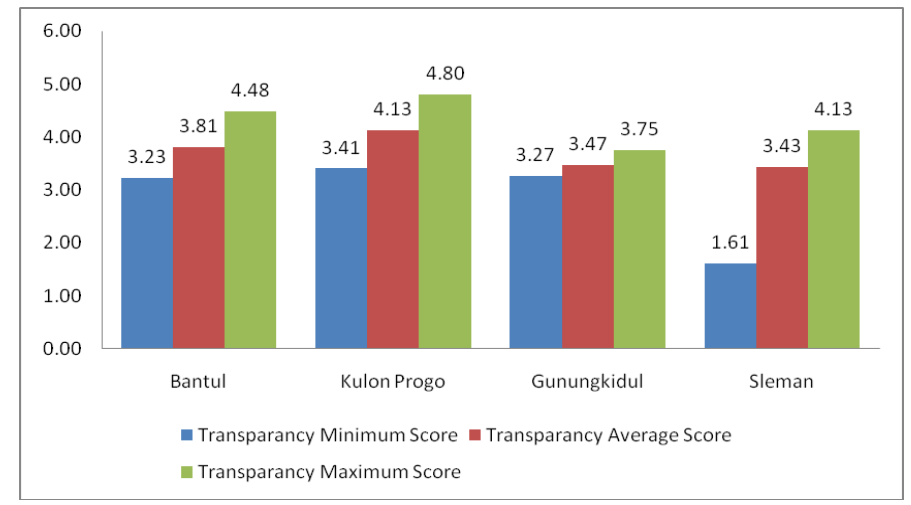

Fig 3. The Practice of Transparency Indicator in the Process of RPJMDes Arrangement in the Four Regencies in DIY

Source:Processed from primary data, Yogyakarta, 2017

In general, the villages in the four regencies encounter very serious problems in implementing transparency indicator. The highest score of transparency implementation in arranging RPJMDes is under 5,00; it shows a very low achievement. That score shows that the atmosphere of decision making in villages is still dominated by the elite in villages. It means that the atmosphere has not included dialogue among them and the participation is not real. The characteristic of planning which is less open is caused by community limited knowledge, limited information and a little village administrator that are able to communicate with community.

\section{Accountability Indicator}

The practice of good governance in the arrangement of RPJMDes is measured by accountability indicator. The indicator is used to find out the capability of Tim Sebelas in fulfilling their responsibility.

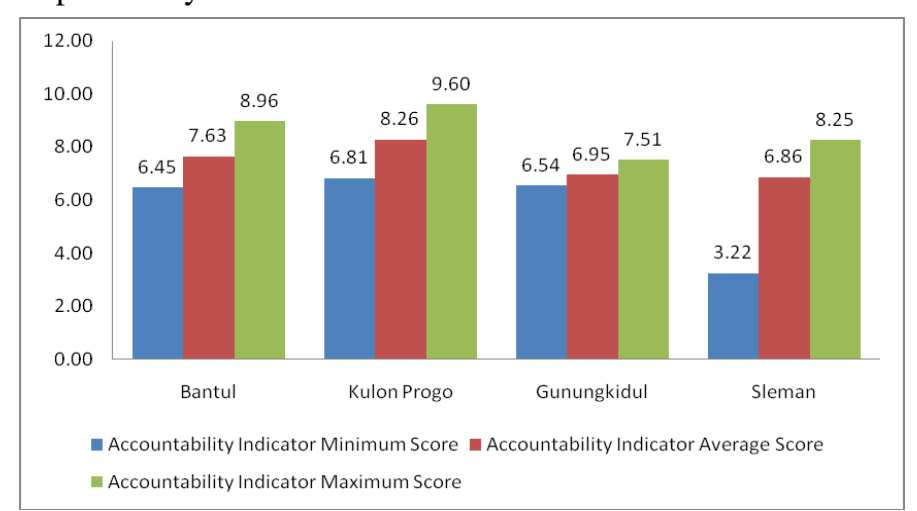

Fig 4. The Practice of Accountability Indicator in the Process of RPJMDes Arrangment in the Four Regencies in DIY

Source:Processed from primary data, Yogyakarta, 2017

The highest and the best average scores of accountability in the arrangement of RPJMDes in the four regencies are consistently achieved by villages in Kulon Progo Regency and Bantul Regency. Medium score is achieved by villages in Gunungkidul Regency while the widest score gap occurs in Sleman Regency. The lowest score of villages in the four regencies is categorized very low. The role of village counselors in Kulon Progo Regency and Bantul Regency is really big to give guidance in implementing accountability. As observed in Focus Group Discussion (FGD), the role of each actor is shown clearly. The accountability of this plan is expressed by the acceptance from the entire parties over the result of RPJMDes formulation which has been validated. The even distribution of village-budget-fund allocation is particularly regarded by stakeholder as a good form of responsibility.

\section{E. Efficient Indicator}

Efficient indicator in the process of RPJMDes document arrangement is directed to the fulfilment of time, budget, energy and other resources standard.

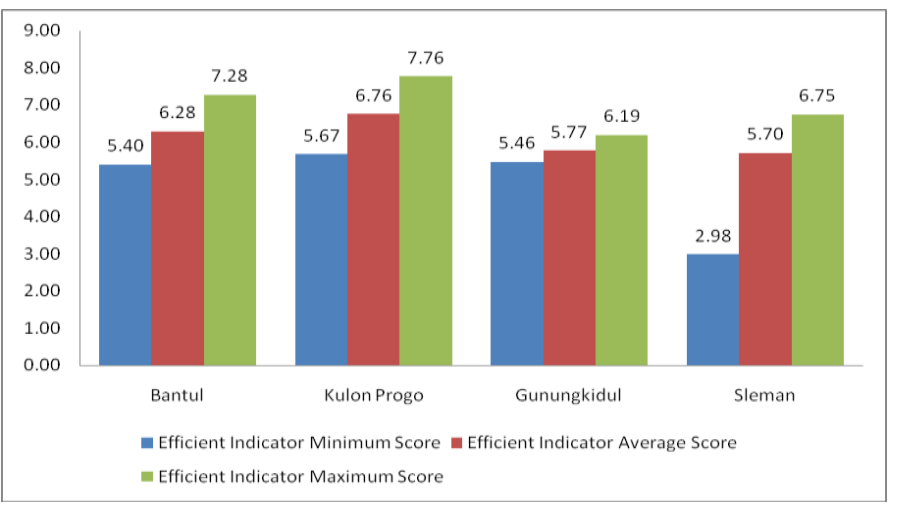

Fig 5. The Practice of Effective in the Arrangement Process of RPJMDes in the Four Regencies in DIY

$$
\text { Source:Processed from primary data, Yogyakarta, } 2017
$$

Sample villages in the four regencies show the low score of efficiency, even the lowest score in Sleman Regency is in extreme point which is 2,98. The highest score is achieved by village in Kulon Progo Regency and is regarded as a fine category with 7,76 . The achievement of high score by village in Kulon Progo Regency is followed by village in Bantul Regency which is categorized as enough, village in Sleman Regency which is categorized as enough and village in Gunung Kidul Regency which is categorized as low. Efficiency indicator score with the highest average is achieved by village in Kulon Progo Regency with a fine category, while the other three regencies have low efficiency indicator score average. The less optimal achievement of this efficiency is marked by the limited human resources, the late in finishing documents, poor planning ability, and poor computer-technical ability in Tim Sebelas.

\section{F. Effective Indicator}

The achievement of effectivity score is higher compared to efficiency score. The measurement of efficiency indicator achievement in the four regencies is more balanced. 


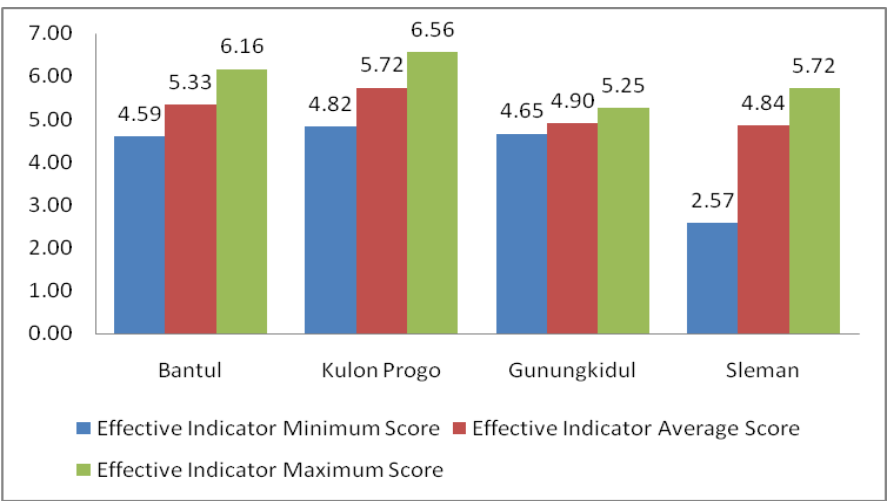

Fig 6. The Practice of Efficient in the Arrangement Process of RPJMDes in the Four Regencies in DIY

Source:Processed from primary data, Yogyakarta, 2017

The highest effectivity score achievement in fine category is reached by village in Kulon Regency, followed by Bantul Regency and Sleman Regency. Effectivity score with the highest average is achieved by village in Kulon Progo, followed by Bantul Regency, Gunung Kidul Regency and Sleman Regency. Meanwhile, effectivity scores ranked from the lowest one are from Sleman Regency, Gunung Kidul Regency and the last is Kulon Progo Regency.

The practice of good governance in the arrangement of RPJMDes as observed by two indicators which is in pairs are efficiency and effectiveness. The two indicators are observed by the process, resources, output and outcome.

The presented data shows score recapitulation from the two paired indicators with the highest score achieved by villages in Kulon Progo Regency and Bantul Regency. The medium score is achieved by villages in Gunungkidul Regency while the widest score gap is from villages in Sleman Regency. The best efficiency and effectiveness achievement is from villages in Kulon Progo Regency and Bantul Regency as shown by the role of village counselors. In addition, there is no role of village counselor in Gunungkidul Regency and Sleman Regency. This condition is complained by village head of Ngipak, Gunungkidul who said "We need counselor, unfortunately most village counselors in here are domiciled in other regency, so that they rarely come". The result of FGD in sample villages in Sleman Regency shows that some stakeholders claim that they do not know the existence of counselor team. Whereas, since the launch of village fund policy, all villages had received village counselors yet did not function optimally.

\section{G. Inter-Regency Comparison Analysis}

It is important to find out the recapitulation result from the evaluation of RPJMDes arrangement in the four regencies in DIY. Comparing the achievement of six indicators of RPJMDes arrangement in the four regencies can show the dissemination of the highest and the lowest RPJMDes scores.

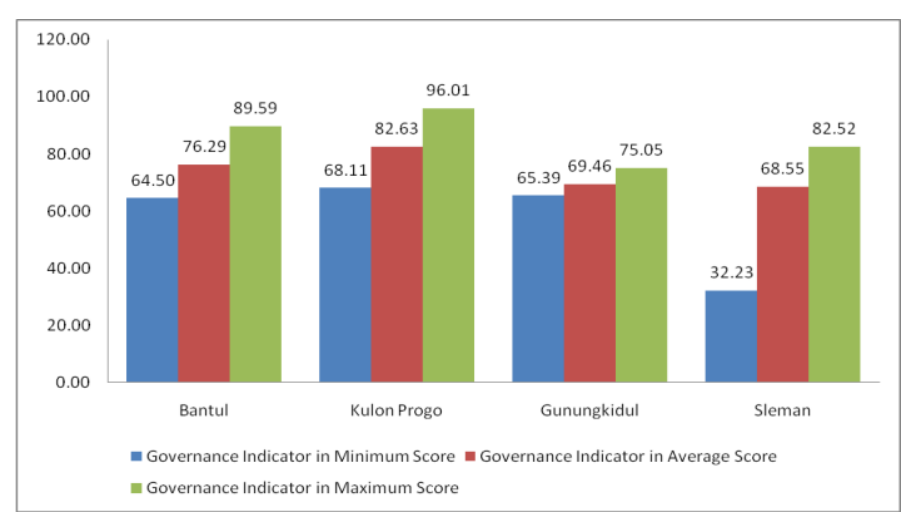

Fig 7. Recapitulation Comparison of the Six Indicators of RPJMDes Arrangement in Each Regency

Source:Processed from primary data, Yogyakarta, 2017

The effectiveness and efficiency in the process of RPJMDes arrangement only consider the budget and time conformity as the background of arrangement process.

Based on the indicator in RPJMDes arrangement process in the four regencies, it can be concluded that the average scores are varied. Villages in Kulon Progo Regency are those that have high average scores in RPJMDes arrangement process. That achievement is followed by Bantul Regency, Gunung Kidul Regency and last is Sleman Regency.

In general, there is tendency of score similarity in the four indicators, which are participation, partiality, accountability, and continuity. The similar scores are caused by the awareness of Tim Sebelas to enforce the implementation of the four indicators. Participative process has existed since hamlet consensus (musyawarah dusun/musdus), continued by consensus system for village development. However, the fact is the participative process is only dominated by some authorized actors. There are still some society groups that have not taken part actively in the arrangement process.

Transparency indicator aspect has the lowest score and is included in deficient category compared to the other indicators. The low score of transparency indicator is caused by weak process done by villages. Transparency is still regarded as a passive role from village which is done by initiating participation. However, the transparency becomes very weak when the participation is still in certain elements only. The actual transparency aspect cannot be well performed.

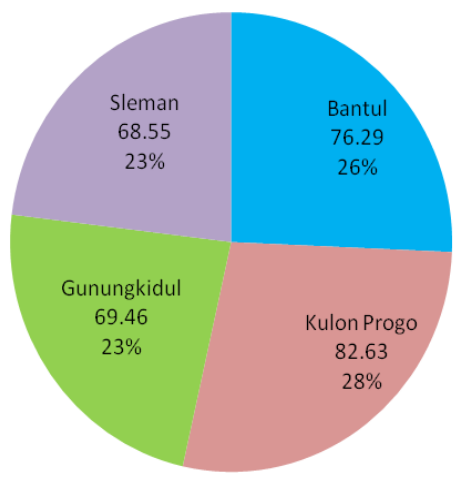

Fig 8. Average Achievement Result of RPJMDes Process Quality Source:Processed from primary data, Yogyakarta, 2017 
Based on the indicators in the process of RPJMDes arrangement in the four regencies can be found that the average scores are varied. Villages in Kulon Progo Regency are those that have highest average scores in the process of RPJMDes arrangement. The second-high average scores are from Bantul Regency which then is followed by Gunung Kidul Regency and Sleman Regency. Further, the highest and the lowest scores of document evaluation result and RPJMDes arrangement process in the four regencies are shown in the following Table 2.

TABLE II. VILLAGES WITH THE HIGHEST AND THE LOWEST

\begin{tabular}{|l|l|l|}
\hline \multicolumn{1}{|c|}{ RPJMDESies } & \multicolumn{1}{c|}{ The Lowest } & \multicolumn{1}{c|}{ The Highest } \\
\hline Bantul & Trirenggo Village & Timbulharjo Village \\
\hline KulonProgo & Panjatan Village & Bendungan Village \\
\hline Gunungkidul & Siraman Village & Bejiharjo Village \\
\hline Sleman & Caturharjo Village & Trimulyo Village \\
\hline
\end{tabular}

Source:Processed from primary data, Yogyakarta, 2017

Village with the highest RPJMDes evaluation result score is marked by a strong bound of togetherness within the actors of Tim Sebelas, village government, LPMD and BPD as well as the characteristics of smooth communication and relationship between village government and society. That conducive atmosphere eases Tim Sebelas to implement the six indicators in RPJMDes arrangement. In contrast, villages with the lowest scores of RPJMDes arrangement evaluation result are characterized by less bound of togetherness and care among Tim Sebelas, village government, LPMD and BPD as well as less of close psychology relationship between village government and society.

\section{CONCLUSIONS AND SUGGESTIONS}

The practice of good governance in the arrangement of RPJMDes in DIY, which is measured by the indicators of participation, partiality to community, transparency, accountability, and efficient-effective, is performed by Tim Sebelas and only some parts which has achieved good scores. Particularly villages in Kulon Progo Regency and Bantul Regency are able to achieve pretty high scores in some indicators such as participation, partiality to community and accountability. Whereas villages in Gunungkidul Regency achieve medium score and villages in Sleman achieve wide score gap. Transparency indicator is really hard to be implemented in the arrangement process of RPJMDes. Particulary efficiencyeffectiveness indicator, all villages in the four regencies achieve medium score which is also tend to be low. Some reasons causing the low score of transparency are the atmosphere of decision making that only occurs in the elite of village and community limited knowledge in development planning. In addition, the low achievement of efficiency-effectiveness is caused by assistance toward Tim Sebelas which has not optimized.

Villages with the highest scores in the four regencies are Timbulharjo (Bantul), Bendungan (Kulon Progo), Bejiharjo (Gunung Kidul) and Trimulyo (Sleman). According to the average score achievement result of villages in each regency, the best score is achieved by Kulon Progo Regency, followed by Bantul Regency, Gunung Kidul Regency and Sleman Regency. Closeness and togetherness atmosphere in communication, whether in Tim Sebelas with village government, social institution and society environment, really determine the achievement of the six indicators in RPJMDes arrangement

In order to improve the quality of good governance practice in the arrangement of RPJMDes, the role of village counselors are needed to help Tim Sebelas and optimize the role of stakeholder by starting intensive communication through village media. Thus, transparency indicator in the arrangement of RPJMDes can be improved. Besides that, the improvement of knowledge about planning toward stakeholder, in general, and Tim Sebelas, in particular, can be achieved by intensive assistance and consultation or training. Therefore, good governance practice in the arrangement of RPJMDes can be improved. Tim Sebelas can start to initiate their active roles in forums in hamlets and social institutions. Besides, Tim Sebelas, village government, LPMD and BPD need to increase solidarity so that the six indicators of RPJMDes arrangement can be optimized.

\section{ACKNOWLEDGMENT}

The purpose of this reseach was to investigate the mediumterm development plan which is the reflection of good governance practice. The result of this study identifies mediumterm development plan in supporting the achievement of good governance in Yogyakarta Special region. Based on the fact that the medium-term development plan gave contribution in establishing good governance, thus it has been arranged recommendation for improvement.

\section{REFERENCES}

[1] Bello. Ashiru. \& Dola, K. (2014). Sustainable development and the role of local governance: Experience from malaysian model regions. International Journal of Humanities and Social Science. Vol. 4 No. 1. January 2014. pp:268-280.

[2] Kazimoto, P. (2013). Assessment of villages financial management challenges and development strategies in Tanzania, Arumeru District. International Journal of Research In Social Sciences. Vol. 3, No.2. Oct 2013. pp:112-118.

[3] Madhavi. K. (2016). Panchayati raj:Towards good governance just as the whole universe is contained in the self so is India contained in the villages, 1st Mahatma Gandhi. International Journal of Humanities and Social Science Invention. Vol.5. No.11. November 2016. pp:57-59.

[4] Martitah, (2013). Strengthening local government institutions towards a good governance. International Journal of Business, Economics and Law. Vol. 2. Issue 3. June 2013. pp:6-10.

[5] Miraftab, F. Beard, V. and Silver, C. (2008). Introduction: Situating contested notions of decentralized planning in the global south in planning and decentralization: Contested spaces for public action in the global south. New York: Routledge. pp1-18.

[6] Muro. Estomih, J. and Namusonge, G.S. (2015). Governance factors affecting community participation in public development projects in Meru District in Arusha in Tanzania. International Journal Of Scientific \& Technology Research. Vol. 4. Issue 06. June 2015. pp:106-110.

[7] Nagendra, H. and Ostrom, E. (2014). Applying the social-ecological system framework to the diagnosis of urban lake commons in Bangalore, India. Ecology and society. 19 (2):67.

[8] Oyeniyi, Bukola Adeyem,. (2011). Waste management in contemporary nigeria: The abuja example. International Journal of Politics and Good Governance. Volume 2. No 2.2. Quarter II 2011. pp:1-18.

[9] Pippidi, Alina Mungiu, 2016, The quest for good governance: Learning from virtuous circles. Journal of Demodracy. Vol. 27. Number 1. January 2016. pp:95-109.

[10] Pramusinto, A. (2006). Building good governance in Indonesia cases of local government efforts to enhance transparency. Paper presented at the 
[14] Subramanian, C. (2012). E-Governance: A key to good governance in India. International Journal of Recent Scientific Research. Vol. 3. Issue. 5. May 2012. pp.305-308.

with National Development Goals. Bandar Seri Begawan Brunai Darussalaam. 13-17 November 2006.

[11] Sebudubudu, D. (2010). The impact of good governance on development and poverty in Africa: Botswara-a relatively successful african initiative. African Journal of Political Science and International Relations. Vol. 4. No. 7. October 2010. pp. 249-262.

[12] Sokphea, Y. Pongquan, S. and Ear, S. 2011. Local good governance of rural infrastructure development planning: Case studies of commune councils in Cambodia. IJERD-International Journal of Environmental and Rural Development. 2-1. pp:59-64.

[13] Suaib, E. Bahtiar. and Bake, J. (2016). The effectiveness of apbd-desa management in west muna regency. Mimbar. Vol.32. No. 2. December 2016. pp. 282-291.

[15] Suhardi. (2015). Pemahaman manajemen pedesaan pada perangkat desa di wilayah Kecamatan Semen Kabupaten Kediri. Nusantara of Reseach. Vol.2 No.1. April 2015. Universitas Nusantara Kediri. hlm:73-83.

[16] Temenggung. Yuswandi, A. (2016). Rural financial management in perspective law no. 6 of 2014 concerning the village. International Journal Of Social Sciences. Vol.43. No.1. 30th March 2016. pp:42-54.

[17] Utomo, S J. (2015). Implementasi kebijakan anggaran pendapatan dan belanja desa (APBDES) untuk meningkatkan pembangunan desa:Studi kasus di Desa Bandung Kecamatan Gedeg Kabupaten Mojokerto. Media Trend. Vol. 10 No. 1. Maret 2015. hlm:19-31. 